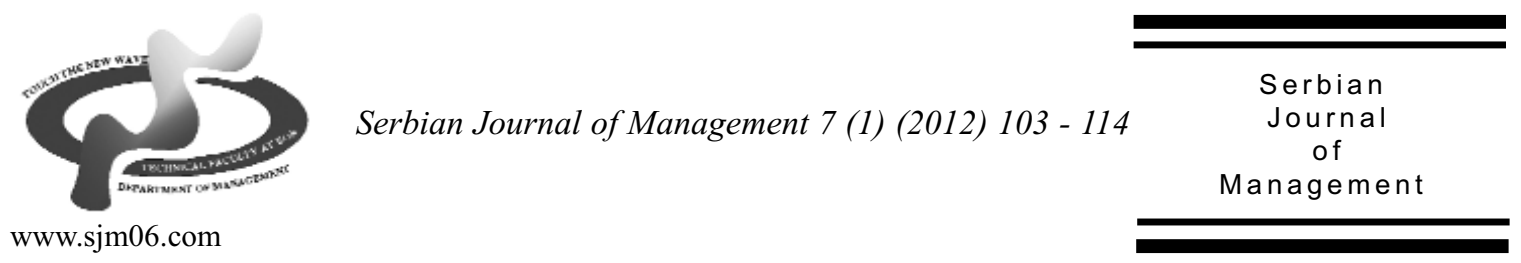

\title{
THE ISSUES IN THE MEASUREMENT OF POSTMATERIAL VALUES
}

\author{
Svetlana Tasića* and Milijanka Ratkovićb

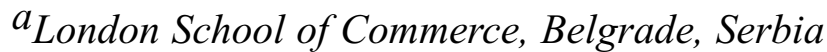

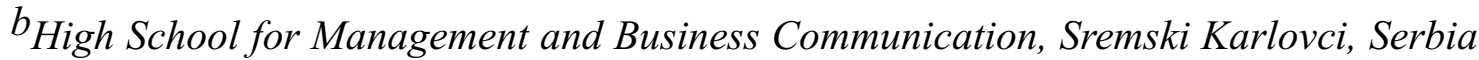

(Received 12 June 2011; accepted 27 October 2011)

\begin{abstract}
The measurement of postmaterial values includes measuring of the views on the preservation of peace, freedom of speech, environmental protection, tolerance and everything else that is contrary to the concept of measuring the material values, that is physical and economic variables. Measurement of postmaterial values is based on the application of 4 or 12 items scale that refers to the materialism or postmaterialism in certain country. There are several issues and limitations in the application of postmaterial values measurement scale which can cause significant error, in other words bias in measurement. One of the most interesting issues is the impact of question order change on the measurement results of postmaterial values. Using the results of empirical research it is shown that this effect is significant and, also it is particularly examined the intensity of this effect considering gender and level of education based on the sample of respondents from urban Serbia.
\end{abstract}

Keywords: postmaterial values, measurement, scale, question order effect, index, marketing research

\section{INTRODUCTION}

In the fields of marketing research there is a special concept of measuring which refers to the measuring of postmaterial values 1 such as peace keeping, freedom of speech, environmental protection, economic

\footnotetext{
*Corresponding author: svetlana.tasic@lsc.edu.rs
}

DOI: $10.5937 /$ sjm1201103T freedom, tolerance etc. These values are opposite to the material ones that include economic and physical characteristics. In the foundation of concept of postmaterial values measurement is measuring the so-called Inglehart's index (Inglehart, 1971, 1977, 1981, 1990, 1997) which combines answers

\footnotetext{
${ }^{1}$ At the beginning Inglehart used the term "post-burgeois " value
} 
to two questions: first about the attitudes of people towards inflation, and second about law and order. Respondents who believe that the issues of inflation and the criminal are less important than those related to the maintenance of freeedom speech and participation in the political processes are considered postmaterialists. The mean answer of these respondents determines a country's attitude toward postmaterialism.

Apart from Inglehart's index some of postmaterial values are measured by other composite indices. One of them is, for example, index of economic freedom which is used for measuring all freedoms and rights of production, distribution or consumption of goods and services. This index is statistical indicator which encompasses 10 specific components: business freedom, freedom of trade, fiscal freedom, government size, monetary freedom, investment freedom, financial freedom, ownership rights, freedom from corruption and labour freedom. Each of these components is measured on a scale from 0 to 100 where 100 represents maximum freedom. The mean value of these 10 components is index of economic freedom. This index spans in the interval from 0 to 100 where values below 50 represent an economically non-free country, and values above 80 indicate that country is economically free. According to the data from "the Heritage" foundation, Serbia is in the $109^{\text {th }}$ place out of 183 world countries based on the value of the index of economic freedom which puts Serbia in the category of "mostly free" countries.

It is considered that in developed industrial societes there is almost linear trend of moving in orientation from material to postmaterial values. Since issues in measuring material values are often debated in litterature, it would also be useful to look at the concept of measuring postmaterial values and some of the problems in applying the same.

\section{THEORETICAL CONSIDERATIONS}

Measuring postmaterial values (constructing of Inglehart's index) is based on the application of 4 items measuring scale. Respondents are asked to choose the most important and the second important national goal i.e. priority out of these 4 options:

1. maintaining the order of the country;

2. giving the people more say in important goverment decisions;

3. fighting rising prices;

4. protecting freedom of speech.

Those who choose options 1 and 3 regardless of the order of their choice are considered materialists; in other words, those who give priority to physical or economic security are materialists. Those who choose any combination of options 2 and 4 are postmaterialists. The mixed category includes respondents who have chosen other combinations of responses.

The aforementioned 4 items scale has been expanded into a 12 items scale (Inglehart, 1995) in order to obtain more reliable measure. This expanded version encompasses 3 separate batteries of questions, each with 4 responses. Each battery includes 2 materialist and 2 postmaterialist items:

I 1. Maintain a high level of economic growth

2. make sure this country has strong defence forces

3. see that people have more say about how things are done at their jobs and 
in their communities

4. try to make our cities and countryside more beautiful.

II 1. Maintain order in the nation

2. give people more say in important government decisions

3. fight rising prices

4. protect freedom of speech.

III 1. A stable economy

2. progress toward a less impersonal and more humane society

3. progress toward a society in which ideas count more than money

4. the fight against crime.

The postmaterialists items are : "more say about jobs and communities", "make our cities and countryside more beautiful", "more say in government decisions", "protecting freedom of speech", "progress toward less impersonal and more humane society" and "progress toward a society in which ideas count more than money". The materialist items are "economic growth", "strong defence forces", "order in the nation", "fighting rising prices", "stable economy" and "fight against crime". After analyzing the structure of these items using the principal component analysis, Inglehart eliminated option " make our cities and countryside more beautiful " from the postmaterial scale as it does not load significantly on postmaterialist factor. Although extended, this version of postmaterial values measurement is less used than the first one.

Measurement of postmaterial values is a concept whose strengths and limitatons in the application are most often discussed in modern literature in the field of marketing research. As an example, Hansen and Tol emphasise that, although it is undeniable that there are considerable difficulties in measuring attitudes of people, the fact is that measurement of postmaterial values show that culture can be measured (Hansen \& Tol, 2003; Velimirovic et al., 2011).

On the other hand, this concept of measuring has been frequently contested in literature, with arguments that measuring of post material values has many shortcomings in its application. Accordingly Tranter and Western accent that postmaterial measurement scale is very sensitive to the change of question order (Tranter \& Western, 2004) which will be thoroughly analyzed further in this paper. In one of the most recent papers Majima and Savage take the opposing position towards Inglehart's classification of materialists and postmaterialists pointing out that the organization of cultural values is complex and cannot be easily summarized by the materialist-postmaterialist dichotomy (Majima \& Savage, 2007). Instead, these authors suggest that it is more appropriate to distinguish between libertarian and authoritarian values, and between conformist and rebellious citizens. Furthemore, Majima and Savage oppose the opinion that in developed countries there is a trend of moving in orientation from materialism towards postmaterialism. They state this based on the overview of value orientation in Great Britain. These authors conclude that there is a little evidence of major change in value orientation between 1981 and 1999 in Britain, especially young people in this country are moving slightly away from postmaterialism, becoming increasingly rebellious and conscientious (Majima \& Savage, 2007). Similar are the conclusions of Roales-Nieto and Segura who conduct a research on value orientation in Spain (Roales-Nieto \& Segura, 2010). They also oppose Inglehart's opinion about the change of value orientation in highly developed 
countries particularly among young people. Results based on a sample of 460 people $^{2}$ did not allow to confirm the intergenerational change of values in Spain. The findings of this study also contradict the theory in other aspects. For example, predominance of materialistic profiles has been observed in all age groups in the reports on personal values (Roales-Nieto \& Segura, 2010).

One of the objections that is contributed to Inglehart's index is that this index is too sensitive to the economic and political fluctuations. For instance, the opinion can be found that inflation rate growth causes increase in the proportion of materialists, while growth of unemployment leads to greater proportion of postmaterialists and mixed category since higher unemployment (which is not included in the index) causes lower inflation (Clarke et al., 1999; Stefanovic et al., 2010). Using multinomial logistic model these authors show how different covariates like education, gender, income and region influence Inglehart's index. In their interpretation, respondents worried about unemployment are forced to choose among items that they worry less about. As a consequence, they are classified as postmaterialists or mixed category. That means that postmaterialism is positively correlated with unemployment (Clarke et al., 1999). Hansen and Tol perform regression analysis in order to look at how several explanatory variables influence the level of Inglehart's index (Hansen \& Tol, 2003). Based on the sample of 14 countries $^{3}$ they examine effect of time trend (from 1970. to 1997.), inflation rate, unemployment rate, gross domestic product per capita and crime rate on the value of Inglehart's index for measuring postmaterial values. The conclusion is that there is significant effect of time trend; in other words there is a trend towards postmaterialism. Higher inflation rates cause lower values of index. Unemployment rate doesn't have significant effect. GDP has a significant positive effect on the greater proportion of postmaterialists. Increase in the crime rate leads to the smaller value of Inglehart's index, which is expected.

\section{RESEARCH PROBLEM AND OBJECTIVES}

The main objective of the research conducted with the purpose of writing this paper is to determine the proportion of postmaterialist in Serbia. Refering to that the following research question was asked: "Is there significantly higher proportion of materialists than postmaterialists in Serbia?". As mentioned before, it is believed that there is greater proportion of materialists comparing to the postmaterialists in economically insufficiently developed countries with low values of indicators of economic power. As evidence of this, the results refering to the proportion of postmaterialists from one of the highly developed countries will be presented in this paper.

The existing research results in the field of postmaterial values measurement that can be found in the literature show that, as noted above, there are certain problems and limitations in measuring these values. The existing findings of the researches from the

\footnotetext{
${ }^{2}$ The whole sample was divided in three groups: Young group (200 participants), Adult group (160 participants) and Senior group (100 participants). The respondents were asked to indicate, by order of importance, personal values that are driving their life (maximum 10 values). The criteria followed to categorize the data obtained with the research were in agreement of the Inglehart's criteria. They were as follows: (a) post-materialistic values, (b) materialists values and (c) values not classifiable according to previous categories. The research was conducted in 2009 in Spain.

${ }^{3}$ The sample includes Argentina, Belgium, Denmark, France, Germany, Greece, Ireland, Italy, Japan, Netherland, Portugal, South Corea, Spain and United Kingdom.
} 
fields of postmaterial values measurement that can be found in the literature show that, as mentioned before, there are certain problems and limitations in measuring these values. By the opinion of the authors of this paper, one of the most interesting issues in the postmaterial values measurement that is presented in the researches so far is the impact of changes to the order of questions on the measurement results of postmaterial values. Tranter and Western conduct research on the sample of Australian inhabitants in which they show that this effect is significant; in other words, change of question order in the scale causes different results about the proportion of postmaterialists comparing to the results that are obtained using the original version of scale (Tranter \& Western, 2004). Furthermore, Tranter and Western also particularly examine impact of some specific factors (gender, belonging to a specific age group (generation), level of education, country of birth) on the intensity of effect of question order alternation. These authors conclude that gender has significant impact on the effect of change of question order meaning that intensity of this effect is greater for men than for women (Tranter \& Western, 2004). Considering the level of education (those who have tertiary education and those who don't), Tranter and Western ascertain significant impact of level of education on the effect of change of question order since they conclude that this effect is smaller for people with tertiary level of education (Tranter \& Western, 2004). They further conclude that there is insufficient evidence to support hypothesis of the imact of age, i.e. belonging to a specific generation (born before the second world war, born in the period 19461959 and born in the period 19601985) on the effect of change of question order (Tranter \& Western, 2004). Finally, these authors draw a conclusion about significant impact of country of birth (Australia, United Kingdom or others) on the size of the question ordering effect (Tranter \& Western, 2004). Based on these results, there are some specific objectives introduced in the research presented in this paper : (1) examination of the impact of gender on the size of question order effect in the postmaterial values measurement among respondents in Serbia and (2) examination of the impact of the level of education on the size of question order effect in the postmaterial values measurement among respondents in Serbia. In accordance with the aforementioned, the following research hypotheses can be derived:

H1: There is significantly greater proportion of materialists than postmaterialists in Serbia (considering the level of economic development).

H2: There is a significant impact of question order effect on the results of measurement of postmaterial values.

H3: There is a significant impact of gender on the size of the question ordering effect in the scale for measuring postmaterial values.

H4: There is a significant impact of education level on the size of the question ordering effect in the scale for measuring postmaterial values.

\section{THE RESEARCH METHOD}

The method of questionnaire based on the convinient sample of 150 Serbian urban households was used for data collection in the empirical research. The research was conducted through face-to face interview in 
Belgrade, Novi Sad and Leskovac during the period from 1.6. 2010. to 22.12. $2010^{4}$. According to the 2002. Census data, there were 1.576.124 inhabitants in Belgrade, 299.294 in Novi Sad, and 156.252 in Leskovac. Following the principles of quota sampling, a convinient sample of 117 households was selected from Belgrade, 23 from Novi Sad and 10 from Leskovac which creates the total sample of 150 households. The respondents were asked following question:

"What is the most important long-term national goal of Serbia? (chose 2 from the 4 offered answers that are most important by your opinion)":

1. maintaining the order of the country

2. giving people more say in important goverment decisions

3. fighting rising prices

4. protecting freedom of speech.

The respondents who select answers 1 and 3 are considered materialists, those who choose answers 2 and 4 are postmaterialists, all other combinations of answers belong to the mixed category.

With the goal of checking the assumption about the effect of changing the order of questions on the results of measurement of postmaterial values the additional research was subsequently performed on a covinient sample of 65 Belgrade inhabitants older than 18 years. To be more precise, two smaller samples were formed, i.e two groups of respondents. The first control group of 30 respondents was offered the original version of Inglehart's scale. The second test group of 35 respondents was also offered 4 items scale but not with the same order of questions as in the original Inglehart's scale.

In order to test hypothesis considering the impact of gender on the size of the question ordering effect, the total sample was divided into men and women (34 females and 31 males). The female sample was afterwards divided into two equal groups : control group with original version of Inglehart's scale and test group with altered order of questions.

Fot the purposes of testing the hypothesis about the impact of the education level on the intensity of question order effect, the total sample was divided into two smaller samples : 30 respondents with higher and high education and 35 respondents with primary and secondary education. Similar to investigating the gender influence, each of these two samples was divided into a control and test group.

With the aim of examining impact of gender and education level on the effect of change of question order it was used $\chi 2$ test of independence. T-test of comparasion of means was exploited for the purposes of verifying the hypothesis about impact of question order effect on the results of measurement of postmaterial values. The empirical research presented in this paper also uses methods of ANOVA and regression analysis in order to produce more evidences for supporting of some of the conclusions. The method of comparative analysis was exploited for the purposes of comparision of results about the proportion of postmaterialists between Serbia and Australia.

The research represented in this paper was carried out in accordance to the research that was conducted by authors Tranter and Western in paper "Question ordering effects in Inglehart's postmaterial index" presented at the "Australasian Political Studies Association" conference in Adelaide, Australia in 2004 (Tranter \& Western, 2004).

\footnotetext{
${ }^{4}$ This research is a part of a much wider research that was performed for the purposes of writing a $\mathrm{PhD}$ thesis with the goal of analyzing the purchasing approach and some attitudes of consumers in Serbia. The question refering to the attitudes towards postmaterialism was one of the 15 questions from the questionnaire.
} 
5. THE RESULTS OF THE RESEARCH AND DISCUSSION

The results of the postmaterial values measurement on the sample of 150 Serbian households are shown in Table 1.

Tabela 1. The results of the postmaterial values measurement on the sample of 150 respondents in Serbia

\begin{tabular}{|l|c|}
\hline & $\%$ \\
\hline Postmaterialists & 15,2 \\
\hline Mixed & 64,2 \\
\hline Materialists & 20,6 \\
\hline Percentage difference index & \\
\hline
\end{tabular}

This sample indicates that there is greater proportion of materialists comparing to postmaterialists in Serbia, which is a distinction of less developed countries, in other words for environments in which there are visible economical and political problems (inflation, unemployment, corruption, etc.). For the purposes of comparasion, data concearning the proportion of postmaterialists from one of the industrialy most developed countries Australia are presented in Table 2. Those data were produced by the research conducted on a sample of 2014 respondents in 2007.

Table 2. Proportion of materialists and postmaterialists in Australia on a sample of 2014 respondents

\begin{tabular}{|l|c|}
\hline & $\%$ \\
\hline Postmaterialists & 35,0 \\
\hline Mixed & 57,2 \\
\hline Materialists & 7,8 \\
\hline Percentage difference index & 27,2 \\
\hline
\end{tabular}

Source: World Value Survey- Australia, 2007.
These data show a legitimacy of the point about a greater proportion of postmaterialists in environments with high levels of the economic growth rate and with no visible economical and political instability.

In order to test hypothesis that there is significantly higher proportion of materialists than postmaterialists in Serbia ttest of comparasion of means was used. It produced very low p-value, significantly lower than 0.05 which implies that, at the 0.05 level of significance, the hypothesis that there is significantly higher proportion of materialists than postmaterialists in Serbia would not be rejected.

Table 3 presents the results in percentage from the control and test group that were formed in order to verify the hypothesis refering to the significance of the impact of question order change.

Table 3. The results of examining the effect of change of question order in Inglehart's scale

\begin{tabular}{|l|c|c|l|}
\hline & $\begin{array}{c}\text { Control } \\
\text { group }\end{array}$ & $\begin{array}{c}\text { Test } \\
\text { group }\end{array}$ & Difference \\
\hline Postmaterialists & 16,1 & 18.3 & $-2,2$ \\
\hline Mixed & 60,4 & 61,0 & $-0,6$ \\
\hline Materialists & 23,5 & 20,7 & $-2,8$ \\
\hline Percentage difference index & $-7,4$ & $-2,4$ & $-5,0$ \\
\hline Sample size & 30 & 35 & 65 \\
\hline
\end{tabular}

The control group shows that materialists prevail in Serbia (percentage difference index is -7.4). Test group, on the other hand, shows that the difference between materialiasts and postmaterialists is significantly smaller (percentage difference index is - 2.4). Based on the $\chi^{2}$ test of independence it can be seen that the difference between two samples is significant $(p$-value $<0,000)$ which confirmes the hypothesis about the significant impact of question order change

\footnotetext{
${ }^{5}$ It is calculated as a percentage of postmaterialists minus the percentage of materialists.
} 
on the measurement results.

Data presented in Table 4 are produced from the investigating of the impact of gender on the size of question ordering effect:
While the hypothesis about the impact of gender on the size of question order effect doesn't seem tenable, until than it can surely be adopted that it is reasonable to assume that the level of education, influences the

Tabela 4. Postmaterial values from the 4 item scale, test and control group by gender (in percent)

\begin{tabular}{|l|c|c|c|c|c|c|}
\hline & \multicolumn{3}{|c|}{ Women } & \multicolumn{3}{c|}{ Men } \\
\cline { 2 - 7 } & Control & Test & Difference & Control & Test & Difference \\
\hline Postmaterialists & 24,2 & 23.3 & $-0,9$ & 16,3 & 25,2 & 8,9 \\
\hline Mixed & 60,1 & 60,6 & 0,5 & 69,6 & 59,0 & $-10,6$ \\
\hline Materialists & 15,7 & 16,1 & 0,4 & 14,1 & 15,8 & 1,7 \\
\hline Percentage difference index & $-8,5$ & $-7,2$ & $-1,3$ & $-2,2$ & $-9,4$ & $-7,2$ \\
\hline Sample size & 17 & 17 & & 15 & 16 & \\
\hline
\end{tabular}

Percentage difference index for men is 7,2 which is considerably higher than for women $(-1,3), \chi 2$ test statistics indicates highly significant question order relationship in the population for men $(\mathrm{p}-$ value $\neg \neg<$ $0,000)$, while this effect for women is not significant at the $5 \%$ level of significance $(\mathrm{p}$-value $=0,160)$. It remains unexamined why the size of question order effect is influenced by gender and this can be the subject of further analysis. size of this effect. It is expected that the effect of change of question order is not significant for the respondents with higher or high education; in other words it is assumed that low value of percentage difference index will be obtained from these respondents, oposite from the respondents with primary or secondary level of education.

The results shown in Table 5 verify the hypothesis of relationship between the level of education and the effect of change of

Table 5. Postmaterial values from the 4 items scale, test and control group by education (in percent)

\begin{tabular}{|l|c|c|c|c|c|c|}
\hline \multirow{2}{*}{} & \multicolumn{3}{|c|}{ Higher and high education } & \multicolumn{3}{|c|}{ Primary and secondary education } \\
\cline { 2 - 7 } & Control & Test & Difference & Control & Test & Difference \\
\hline Postmaterialists & 21,1 & 21,9 & 0,8 & 17,4 & 24.9 & 7,5 \\
\hline Mixed & 59,5 & 58,4 & $-1,1$ & 66,8 & 59,0 & $-7,8$ \\
\hline Materialists & 19,4 & 19,7 & 0,3 & 15,8 & 16,1 & 0,3 \\
\hline Percentage difference index & $-1,7$ & $-2,2$ & $-0,5$ & $-1,6$ & $-8,8$ & $-7,2$ \\
\hline Sample size & 12 & 18 & & 19 & 16 & \\
\hline
\end{tabular}


question order. Namely the percentage difference index for the respondents with primary and secondary education is considerably higher, meaning that the size of effect of question order change is bigger for the people with lower level of education. Also, it is important to note that there is a greater proportion of postmaterialists among people with higher levels of education which is also a quite expected finding.

In order to obtain additional evidence for the significance of impact of education level on the size of effect of question order change, the ANOVA analysis was also performed. The aim was to test whether factor "level of education" influence the mean of target variable "percentage different index" (by the opinion of authors this variable most adequately indicates the size of the question order change). ANOVA provides good assessment of the impact of controllable social factor (level of education) on the level of effect of change of question order . In other words, the goal is to compare three means (three levels of education), i.e. to test hypothesis about the significance of the impact of level of education on the intensity of the effect of change of question order in postmaterial measurement scale. Since ANOVA requires at least three groups, the above mentioned sample of 65 respondents 6 was divided into 3 subsamples: secondary education or lower $(32$ respondents), higher education (21 respondents) and high level of education (12 respondents). Results of the percentage difference index for each respondent of all 3 groups were input in ANOVA. Table 6 represents results produced by ANOVA. The first part of Table 6 shows means and variances of percentage difference indices for each of the groups, while the second part provides basic ANOVA indicators.

The ANOVA produced low level of $p$ value (.00104) which verifies the hypothesis of the significance of influence of education

Table 6. The results from ANOVA analysis

\begin{tabular}{ccccc}
\hline SUMMARY & & & & \\
\hline Groups & Count & Sum & Average & Variance \\
\hline Secondary or lower & 32 & $230.4^{*}$ & $7.2^{*}$ & 1.7 \\
Higher & 21 & $67.2^{*}$ & $3.2^{*}$ & 0.7 \\
High & 12 & $28.8^{*}$ & $2.4^{*}$ & 0.8 \\
\hline
\end{tabular}

*these are absolute values of PDI

ANOVA

\begin{tabular}{|c|c|c|c|c|c|c|}
\hline Source of Variation & $\begin{array}{c}\text { Sum of } \\
\text { squares }\end{array}$ & $\begin{array}{c}\text { Degrees } \\
\text { of freedom }\end{array}$ & Mean square & F statistics & P-value & F critical \\
\hline Between Groups (level of education) & 6.98 & 2 & 3.49 & 6.25 & .00104 & 3.145258 \\
\hline Within Groups & 34.62 & 62 & .557 & & & \\
\hline Total & 41.6 & 64 & & & & \\
\hline
\end{tabular}

${ }^{6}$ This sample was used to form test and control groups. 
level . To be more precise, this influence is significant for every level of significance below $0.104 \%$ which produces enough evidence for the confirmation of hypothesis that there is significant impact of level of education on the size of effect of question order change since ANOVA controllable factor (education ).

Finally, the regression analysis was performed in order to produce as reliable conclusions of the whole analysis about the question order influence as possible. Gender and education (higher and high level or not) were selected for explanatory variables while percentage difference index was dependent one since it shows the size of question order effect. A dummy variable (test group) was also created in order to measure the size of effect of question order change between test and control groups. The three separate regression models are created: one for the whole sample of 65 , the other two separate men from women. Table 7 presents the results that were produced by regression analysis.

\section{Table 7. The results from regression analysis}

\begin{tabular}{|l|l|l|l|}
\hline & Full sample & Women & Men \\
\hline Intercept & 68.8 & 67.4 & 66.9 \\
\hline Women & 0.28 & -- & -- \\
\hline Higher or high education & $7.2^{*}$ & $3.9^{*}$ & $9.1^{* *}$ \\
\hline Test group & $-5.1^{* *}$ & $-3.9^{* *}$ & $-5.3^{* * *}$ \\
\hline $\begin{array}{l}\text { Mean of dependent variable } \\
\text { (percentage difference index) }\end{array}$ & -7.7 & -5.2 & -10.2 \\
\hline Adjusted R squared & .06 & .09 & .06 \\
\hline Sample size & 65 & 34 & 31 \\
\hline$* 05 * *$ p $01 * * *$ & 001 & & \\
\hline
\end{tabular}

*p $.05 \quad * *$ p $.01 \quad * * *$ p .001

The regression analysis allows estimation of known predictors of postmaterial value attitudes. It also provides more conclusive test of the question order effect. Low pvalues were produced for independent variable refering to education, i.e."higher or high education" which is additional evidence for the significance of the education influence. Furthermore, p-values refering to education influence are lower for men than for women which brings to conclusion that the effect of change of question order is stronger for men. There are also low pvalues for the dummy predictor "test group" which supports conclusions that were brought previously refering to the second hypothesis of this paper about the significance of impact of question order effect on the results of measurement of postmaterial values.

Using additional analysis it can also be examined the existance of relationship between age and the effect of question order change or between place of living (urban or rural areas) and the size of this effect etc.

\section{CONCLUSION}

The measurement of postmaterial values as a form of data collection about attitudes and values certainly represents an important segment of marketing research in the sense that it can be the source of valuable information and, at the same time, it is a good demonstrator that non-material variables can successfully be measured. However, it is undeniable that there is a significant number of limitations and weaknesses in the implementation of this measurement which, if not carefully treated, can raise the implications of the validity and reliability of results. This paper indicates to problems, i.e. measurement errors that are caused by change of question order in the 
measurement scale. It has been shown that to be expected that in the future period the the effect of question order change is statistically significant and also the size of this effect is significantly higher for men than for women and for people with lower education. Paper also presents results of significantly higher proportion of materialists in Serbia comparing to the percentage of postmaterialists. This is quite expected considering the level of Serbian economic development. However, it is also proportion of postmaterialists will increase, in accordance with current tendencies.

In modern literature disscusions on various advantages and disadvantages of postmaterial values measurement can be found. The opinion of the authors of this paper is that additional testing and analysis must be done in order to produce more reliable conclusions about this concept.

\title{
ПРОБЛЕМАТИКА МЕРЕЊА ПОСТМАТЕРИЈАЛНИХ ВРЕДНОСТИ
}

\author{
Светлана Тасић и Милијанка Ратковићб

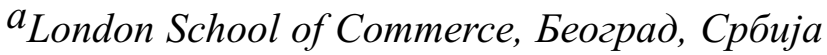

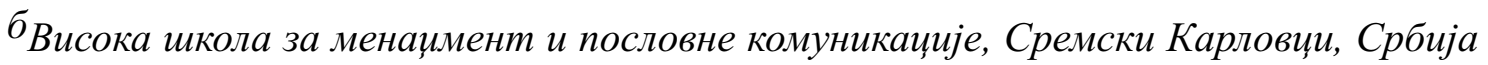

\section{Извод}

Мерење постматеријалних вредности обухвата мерење ставова о очувању мира, слободе говора, животној средини, толеранцији и о свему другом што представља супротан концепт од мерења материјалних вредности тј. физичких и економских варијабли. Мерење постматеријалних вредности заснива се на примени скале од 4 или 12 ставова о материјализму и постматеријализму на основу чега се добијају подаци о учешћу материјалиста, односно постматеријалиста у некој земљи. Постоји више проблема и ограничења у примени скале за мерење постматеријалних вредности што може бити узрок значајне грешке односно пристрасности у мерењу. Један од интересантнијих проблема је утицај измене редоследа питања на резултате мерења постматеријалних вредности. На основу резултата емпиријског истраживања је показано да је овај утицај сигнификантан а посебно је испитивана јачина овог ефекта са аспекта пола и нивоа образовања на узорку испитаника из градова Србије.

Кључне речи: постматеријалне вредности, мерење, скала, ефекат редоследа питања, индекс, маркетинг истраживања 


\section{References}

Clarke, H.D., Kornberg, A., McIntre, C., \& Kaase, M. (1999) The effect of economic priorities on the measurement of value change: New experimental evidence. American Political Science Review, 93(3): 166-177.

Hansen, O., \& Tol, R.S.J. (2003) A refined Inglehart index of materialism and postmaterialism. American Political Science Review, 73(3): 155-169.

Inglehart, R. (1971) The silent revolution in Europe: Intergenerational change in postindustrial societies. American Political Science Review, 65(4):122-134.

Inglehart, R. (1977) The silent revolution: Changing values and political styles among western publics. Princeton: Princeton University Press.

Inglehart, R. (1981) Post-materialism in an environment of insecurity. American Political Science Review, 75(4):124-137.

Inglehart，R. (1990) Culture shift in advanced industrial societies. Princeton: Princeton University Press.

Inglehart, R. (1995) Measuring postmaterialism. American Political Science Review, 93(3): 144-157.

Inglehart, R. (1997) The trend towards postmaterialist values continues. Pp. 162168. in N. Clark \& M. Rempel (Eds.), Citizen Politics in Post-industrial societies, Boulder and Oxford: Westview Press.

Majima, S., \& Savage, M. (2007) Have there been a culture shifts in Britain? A critical encounter with Ronald Inglehart. Cultural Sociology, 3: 293-315.

Roales-Nieto, J.G., \& Segura, A. (2010) Intergenerational differences in materialism and postmaterialism values in a Spanish sample. International Journal of Psychology and Psychological Therapy, 10(3) : 499-512.
Stefanovic, I., Damnjanovic, P., \& Jasko. O. (2010) The analysis of the contemporary environment impact upon organizational operations. Serbian Journal of Management, 5(1): 97-109.

Tranter, B., \& Western, M. (2004) Question order effects in Inglehart's postmaterial index. Pp. 1-27. in Australasian Political Studies Association Conference, University of Adelaide.

Velimirovic, D., Velimirovic, M., \& Stankovic, R. (2011) Role and importance of key performance indicators measurement. Serbian Journal of Management, 6(2): 63-72. 